\title{
Han, Byung-Chul. La sociedad paliativa: el dolor hoy. Barcelona: Herder, 2021.90 pp.
}

\author{
José Daniel Gómez Serna ${ }^{1}$
}

$\checkmark$ racias a su escritura concisa, sin rodeos y amena, el filósofo surcoreano Byung-Chul Han expone una reflexión en torno al concepto de dolor en la actualidad. Esta obra asume un rasgo interesante en su composición y es el hecho de haber sido acabada y publicada en el transcurso de la pandemia de la covid-19 (2020) en su versión original en alemán. Aunque a través de los once breves apartados que componen la obra, Han entra en diálogo con pensadores contemporáneos como Adorno, Heidegger, Nietzsche, Freud, Benjamin, Hegel y Lévinas, entre otros, aparece un interlocutor, de principio a fin: se trata del filósofo alemán del siglo XX Ernst Jünger con su ensayo Sobre el dolor, escrito en 1934.

En esta obra, Han parte de la premisa de que hoy impera en todas partes una "algofobia" (I), término derivado del griego algos (dolor) y phobos (miedo), que el autor traduce como un "miedo generalizado al sufrimiento". ${ }^{2}$ Esto como producto del cambio de paradigma ya señalado por él mismo en obras como La expulsión de lo distinto (2017) o La agonía del eros (2018), mutación que ha consistido en el paso hacia una sociedad de la positividad que busca la complacencia a toda costa, eliminar el dolor como llave de acceso a la negatividad y erradicar sus efectos de purificación y catarsis. ${ }^{3}$

Además, el autor sugiere que el sentido y la función del dolor en la cultura se configura a través de la relación que se establece entre aquel y el poder. Para sustentar esta idea, retoma la actitud de la sociedad disciplinaria ${ }^{4}$ en la cual el dolor era formativo para un hombre considerado como medio de producción. ${ }^{5}$ Luego, muestra que, en la transición hacia un régimen neoliberal, el dolor es vaciado de su sentido y utilidad: "A diferencia del cuerpo disciplinado, el cuerpo hedonista, que se gusta y se disfruta a sí mismo

1 Doctorando en Filosofía de la Universidad Pontificia Bolivariana, Colombia. Correo electrónico: jose.gomezse@upb. edu.co.

2 Byung-Chul Han, La sociedad paliativa (Barcelona: Herder, 2021), 11.

3 Han, La sociedad paliativa, 14.

4 Michel Foucault, Vigilar y castigar: Nacimiento de la prisión (Buenos Aires: Siglo XXI, 2002).

5 Han, La sociedad paliativa, 20. 
sin orientarse de ninguna manera por un fin superior, desarrolla una postura de rechazo hacia el dolor"; ${ }^{6}$ este es desvinculado del poder y es relegado exclusivamente al ámbito médico, e impone la obligación de ser feliz (II).

Por otra parte, la pandemia de la covid-19 reflejó cómo una sociedad paliativa recrudece la Supervivencia (III), pues el dolor como una premonición de la muerte, al ser rechazado en todas sus manifestaciones, implica un empobrecimiento de la vida, es decir, el miedo a morir lleva a una incapacidad de vivir bien y a la mera supervivencia. Esta situación tiene como otra de sus causas la crisis comunicativa en la que nos encontramos. Cuando la vida deja de ser narrada, es limitada a la medición y el cálculo, pierde su sentido y genera el sin sentido del dolor (IV).

Por más que con analgésicos se pretenda anular todo sufrimiento, no puede olvidarse la astucia del dolor (V), la cual consiste en que el dolor, al ser acallado, no desaparece, sino que se transforma: "en la sociedad paliativa, que es hostil al dolor, se multiplican los dolores mudos [...] El sujeto instado a rendir guerrea contra sí mismo. Las presiones internas que surgen entonces lo sumen en la depresión"7 Ante esa sobrecarga o agotamiento de la existencia, tal sujeto encuentra un aliciente o liberación en la autolesión.

En el apartado VI, titulado "Dolor como verdad", nos encontramos con una curiosa descripción del dolor a través de tres predicados nominales, como manifestación de su verdad. Se confiesa que el dolor es vínculo, diferencia y realidad. En los siguientes cuatro apartados, ya no aparecerá el tema de estudio, en términos gramaticales, en caso nominativo sino en genitivo, es decir, no será el sujeto de la oración sino el complemento del nombre. En resumen, propone una poética del dolor (VII): "el dolor mueve al espíritu a construir un mundo salvífico opuesto al mundo existente y que haga la vida más fácil"; ${ }^{8}$ una dialéctica del dolor (VIII): "el dolor hace que el pensamiento sea más profundo [...] es lo único que transforma la inteligencia en espíritu";" una ontología del dolor (IX): "el dolor no es una sensación subjetiva que remira a una carencia, sino una fecundación o concepción, incluso una concepción del ser. El dolor es don"; ${ }^{10}$ y una ética del dolor (X): "sin sentir dolor por el otro no tenemos forma de acceder al dolor del otro". ${ }^{11}$

Por último, se arriba a una profecía a partir de la pandemia, retomando el libro de Francis Fukuyama El fin de la historia (1992), específicamente el capítulo final sobre "El último hombre" (XI), título que también toma para este apartado. El filósofo radicado en Alemania critica al escritor americano por el hecho de haber ubicado a "los últimos hombres" de la historia en la democracia liberal, ya que, para nuestro autor, a partir de la pandemia se irá instaurando un régimen de vigilancia digital que asume rasgos totalitarios. ${ }^{12}$ Pero no solo esto, fatalmente avizora un futuro sin seres humanos, ya que con los avances del transhumanismo se llegará a un punto en el que se dé la liberación total del aburrimiento, el dolor o el sufrimiento, a lo que sentencia Han: "Pero una vida sin muerte ni dolor ya no es una vida

\footnotetext{
6 Han, La sociedad paliativa, 22.

7 Han, La sociedad paliativa, 46.

8 Han, La sociedad paliativa, 47.

9 Han, La sociedad paliativa, 63.

10 Han, La sociedad paliativa, 76.

11 Han, La sociedad paliativa, 82.

12 Han, La sociedad paliativa, 86.
} 
humana, sino una vida de muertos vivientes”. ${ }^{13}$ ¿Es una concepción pesimista del futuro? ¿O nada más que realista?

\section{Bibliografía}

Foucault, Michel. Vigilar y castigar: Nacimiento de la prisión. Buenos Aires: Siglo XXI, 2002.

Fukuyama, Francis. El fin de la historia. Barcelona: Plantea, 1992.

Han, Byung-Chul. La expulsión de lo distinto: El dolor hoy. Barcelona: Herder, 2017.

Han, Byung-Chul. La agonía del Eros. 2. ${ }^{a}$ ed. Barcelona: Herder, 2018.

Han, Byung-Chul. La sociedad paliativa: El dolor hoy. Barcelona: Herder, 2021.

13 Han, La sociedad paliativa, 90. 